\title{
Radiogenic isotopes and the interpretation of granitic rocks
}

Three decades ago, radiogenic isotopes in geological studies were used primarily for obtaining crystallisation ages for igneous rocks, but developments in isotope geochemistry now allow a range of processes to be investigated that both pre-and postdate crystallisation. Many early studies, based on whole-rock analyses, have generated erroneous crystallisation ages as subsequently revealed by high-precision chronometry of accessory phases. Of these, zircon is the most widely used, but monazite and xenotime can also generate precise ages from peraluminous magmas, whereas allanite has been used with success in metaluminous granitoids. Complex cooling histories can be traced by the use of minerals with appropriate closure temperatures. Single crystal zircon evaporation techniques and in-situ electron microprobe analysis of monazites provide new methods for rapid and inexpensive dating of some granites, but both approaches are limited by the range of granites that can be dated and by the assessment of realistic uncertainties. Accessory phase dissolution in felsic melts underpins the use of these minerals in chronometry and also in the interpretation of model Nd ages in constraining the time of crust formation. Ongoing research suggests that disequilibrium studies can potentially constrain the rates of melt formation and extraction although more precise measurements on diffusion rates of critical trace elements are now required.

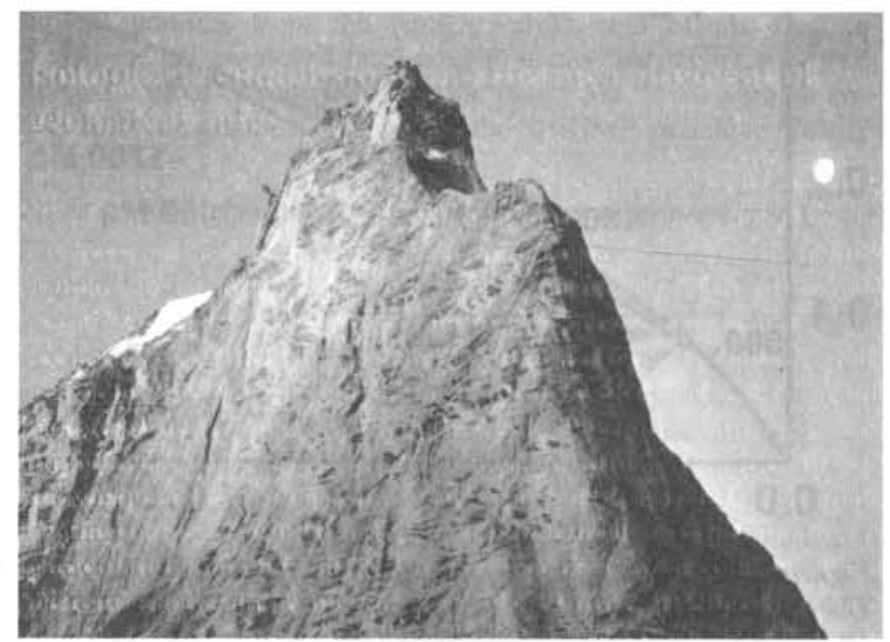

Figure 1(a) The Gumberanjun leucogranite from Zanskar Himalaya, NW India. Metasedimentary enclaves within the granite appear undisturbed relative to fabrics in the country rock.

\section{Introduction}

Granitic rocks constitute a significant proportion of the continental crust, and through their study geochemists can learn about the processes that differentiated the Earth's outer layer from the mantle and about the evolving thermal history of the crust in different tectonic environments. Granite magmas differ from basic magmas not only in their bulk chemistry but also in physical characteristics such as their high viscosities and their lower temperatures of crystallisation. They are also more complex in that basaltic magmas represent, with few exceptions, mantle melts, whereas granites are derived from a diversity of source regions, and result from complex interactive processes. Perhaps most important of all for isotope studies, the majority of trace elements in granites are concentrated in accessory phases and so, advances in the application of radiogenic isotopes to the dating of granites are closely linked to advances in our understanding of the behaviour of accessory phases in granitic magmas.

In this review three aspects of isotope geochemistry are examined; establishing the crystallisation age of a granite, identifying its source and constraining the rates at which heating and melt extraction in the source region proceed.

\section{Crystallisation ages of granites}

Radiogenic isotopes, when correctly interpreted, can be used to date a series of events in the history of a granite; the age of its source, its crystallisation age and the time at which it cooled through the closure temperatures of its component minerals. For deformed granites, deformation ages can also be obtained where isotopic studies are integrated with fabric analysis. However, for most geologists, dating a granite is shorthand for determining the time elapsed since the granite crystallised from the melt.

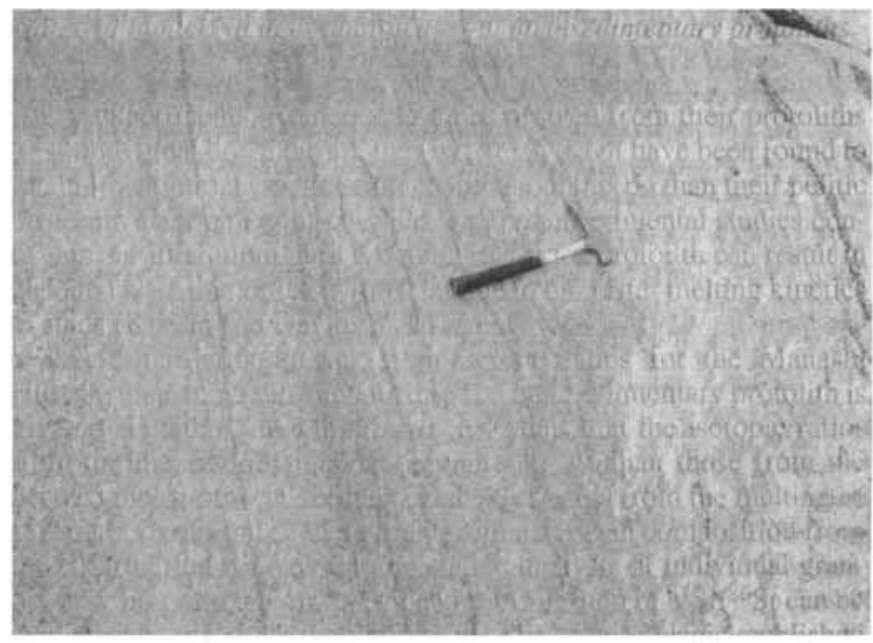

Figure 1(b) Strong igneous layering of arfvedsonite in peralkaline granite (Midian granite, northern Saudi Arabia). 


\section{Bulk rock analysis}

Granite crystallisation ages have been obtained either from mineral chronometry or from whole-rock isochrons. Traditionally potassium-bearing minerals, like micas or alkali feldspars, have been dated using the decay of ${ }^{40} \mathrm{~K}$ to ${ }^{40} \mathrm{Ar}$. However the ready diffusion of a gaseous daughter product such as argon, means that the K-Ar system can only record ages close to the time of crystallisation where crystallisation of the granite has been followed by rapid cooling. The most common whole-rock method used for determining crystallisation ages derives from the analysis of $\mathrm{Rb}-\mathrm{Sr}$ isotopes in bulk-rock samples. This method is based on the assumption that Sr-isotope ratios $\left({ }^{87} \mathrm{Sr} /{ }^{86} \mathrm{Sr}\right)$ will be homogenised throughout the magma chamber. If true then the isotopic ratios ${ }^{87} \mathrm{Rb} /{ }^{86} \mathrm{Sr}$ and ${ }^{87} \mathrm{Sr} /{ }^{86} \mathrm{Sr}$ from whole-rock samples will define a linear array (an isochron). Unfortunately many granitic melts are derived from inhomogeneous source regions and are liable to contamination prior to crystallisation. The high viscosity of granite magmas, combined with low melt volumes characteristic of many granites, conspire to prevent the development of an effective convective system. Consequently the isotopes remain heterogeneous within the intrusion. The result is that bulk-rock analyses of granites only rarely yield a true isochron, and the geochronologist has to choose between accepting a large uncertainty on the age or rejecting samples from the array for the pragmatic reason that they do not lie on the line.

Visual evidence for the lack of convection of a granite magma is sometimes apparent where enclaves systematically preserve fabrics that align with regional structures preserved in the country rock. These are particularly common in low-temperature, crustally derived peraluminous granites as exemplified by High Himalayan leucogranites (Le Fort, 1991). Detailed examination of such granites usually provides evidence for a composite intrusion that results from multiple intrusions of granite sheets (Figure la). In such cases a 'magma chamber' never existed as a single molten mass and no large-scale convection was possible. In contrast peralkaline granites are formed at much higher temperatures with high fluorine abundances, both of which lower the viscosity of the magma. Consequently features such as strong igneous layering are common (Figure lb) often associated with syn-sedimentary structures that characterise convecting magma systems such as the Skaergaard intrusion. Such igneous bodies are more likely to yield well-defined bulk-rock isochrons.

The Manaslu Himalayan leucogranite from northern Nepal is one of the most intensively studied of all orogenic granites. Several $\mathrm{Rb}-\mathrm{Sr}$ bulk-rock studies, based on widely spaced sampling of seemingly homogeous granite, failed to obtain a whole-rock isochron until a more carefully controlled sample programme on the $100 \mathrm{~m}$ scale yielded a linear array which defined an age of $18.1 \pm 0.5 \mathrm{Ma}$ (Deniel et al., 1987). Importantly, to obtain the array it was neccessary to exclude six samples that lay off the line from a set of 17. By restricting the sampling to a smaller area these workers hoped to demonstrate that homogenisation had occurred at least locally within the magma.

More recently the constituent minerals of a sample from the same granite were separated and analysed to generate an 'internal' isochron; using apatite, alkali feldspar and muscovite an age of $21.3 \pm 0.4$ Ma (Copeland et al., 1990) was obtained. A mineral isochron implies that equilibrium has been reached over the scale of a few millimetres which is much more probable than on the scale of an intrusion. However, internal isochrons should generate younger ages than the crystallisation age since individual minerals become closed systems at sub-solidus temperatures. In the Manaslu study the bulk-rock isochron appears to have yielded an erroneously young age. This was confirmed firstly by ages of $22-23 \mathrm{Ma}$ from ${ }^{40} \mathrm{Ar} /{ }^{39} \mathrm{Ar}$ analysis of hornblende from the metamorphic aureole (Guillot et al., 1994). Since hornblende closes to Ar at temperatures of $\sim 500^{\circ} \mathrm{C}$ these ages must be cooling ages and so they place a minimum constraint on the crystallisation age. Secondly an accessory phase in the granite (monazite) was dated at $22.3 \pm 0.5 \mathrm{Ma}$ by an ion microprobe technique described below (Harrison and McKeegan, 1994). Both approaches suggest that the apparent bulk-rock emplacement age of $\sim 18 \mathrm{Ma}$ must be too young, which throws doubt on the selection criteria for the samples that defined the bulk-rock 'isochron'.

Dating the crystallisation age of a granite becomes particularly valuable if the granite provides a time-marker in the tectonic history of an orogenic belt. An example of such a marker is Ben Vuirich, a peraluminous granite intruding the polymetamorphic terrain of the Dalradian in Central Scotland. Because the intrusion is strongly deformed by fabrics that can be correlated with the structural history of the Dalradian an accurate age of intrusion provides a chronological peg on which to hang much of the early history of this complex orogen. An early attempt to date the Ben Vuirich granite by $\mathrm{Rb}-\mathrm{Sr}$ whole-rock analysis yielded a poorly defined sub-linear array (sometimes known as an errorchron) with an 'age' of $552 \pm 24$ Ma (Pankhurst and Pidgeon, 1976). However these authors recognised that a more accurate definition of the age could be obtained by using zircons.

\section{Zircon chronometry}

Zircon (zirconium silicate) is a common accessory phase that has long been favoured for dating granites (zircon chronometry is less useful in the dating of basic rocks due to the rarity of zircon in lowsilica melts). The suitability of zircon as a chronometer lies in the virtual absence of $\mathrm{Pb}$ in crystallised zircons, coupled with a high $\mathrm{U}$ abundance. Consequently a high proportion of analysed $\mathrm{Pb}$ is radiogenic in origin. The high $\mathrm{U} / \mathrm{Pb}$ ratios provide two decay systems $\left({ }^{235} \mathrm{U}-{ }^{207} \mathrm{~Pb}\right.$, and $\left.{ }^{238} \mathrm{U}-206 \mathrm{~Pb}\right)$ each of which defines an independent age. When ${ }^{207} \mathrm{~Pb} /{ }^{235} \mathrm{U}$, and ${ }^{206} \mathrm{~Pb} /{ }^{238} \mathrm{U}$ are plotted against each other the locus of all points that represent the same age in both systems defines a curve known as concordia (Figure 2). Analysed zircons must either lie on concordia (in which case both the two decay systems yield similar ages) or lie off the curve (in which case the zircon is termed discordant). There are two probable causes of discordance. Firstly $\mathrm{Pb}$ may have been lost from the zircons, a process enhanced by radiation damage brought about by the decay of uranium. Secondly the zircons may not have formed at the same time and include overgrowths on older cores in which case the analysed point on the concordia diagram results from a mixture between the various component growth ages. The concordia diagram therefore provides a powerful check on whether the U-Pb isotope systematics may be interpreted as yielding a simple crystallisation age. Interestingly the problem of inherited ages is particularly acute in peraluminous granites. For peralkaline magmas, their higher temperatures and fluorine

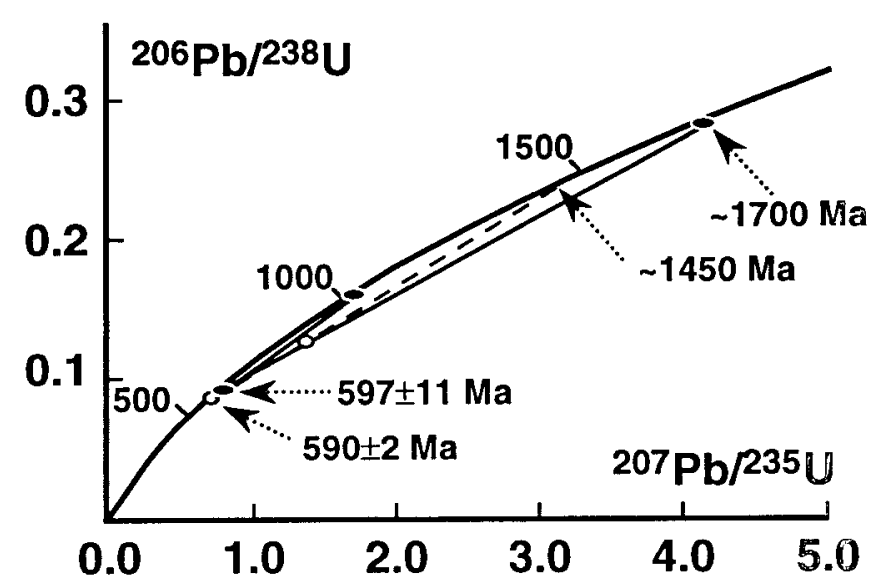

Figure 2 Concordia diagram for zircons from Ben Vuirich. Thick solid curve indicates concordia with ages indicated at 509, 1000 and $1500 \mathrm{Ma}$. Open symbols and dashed line = data fields and chord from conventional zircon analysis (Rogers et al., 1989); filled symbols and solid lines = data fields and chords from ion-probe data; (Pidgeon and Compston, 1992). 
contents greatly increase the solubility of zircon in the melt so that any grains initially entrained in the magma quickly dissolve.

The initial Ben Vuirich study determined that the zircons had formed at $514 \pm 6 \mathrm{Ma}$ but that there was some discordance due to the inheritance of older zircon cores that were dated at $\sim 1300 \mathrm{Ma}$ (Pankhurst and Pidgeon, 1976). The older age was attributed to the age of the sediments that provided the protoliths for the granite melts. It was concluded that the bulk-rock $\mathrm{Rb}-\mathrm{Sr}$ age was incorrect confirming that isotopic homogenisation had not occurred during magma formation. Many papers were subsequently written on the assumption that early metamorphism in the Dalradian had continued until $514 \mathrm{Ma}$ and that fabrics correlated with the deformation of Ben Vuirich postdated this time.

However, in the past few years, a second zircon study of the granite has been published that applies the pioneering methods of Krogh (1982) who recognised the importance of zircon grain selection, rejecting grains that had undergone cracking and radiation damage and abrading zoned crystals to distinguish core from rim. By simultaneously developing low-blank chemistry and high-precision mass spectrometry zircons were coaxed into yielding much more accurate and specific information than was hitherto possible. For example, in the case of Ben Vuirich Rogers et al. (1989) isolated an unzoned, euhedral zircon population which provided concordant ages of $590 \pm 2 \mathrm{Ma}$ and a second population of stubby crystals with cores of $\sim 1450 \mathrm{Ma}$ (Figure 2 ). By this method the crystallisation age was pushed back over 70 million years from the Late Cambrian to the Neoproterozoic $(590 \mathrm{Ma})$. The regional implications of this study are far-reaching for it requires that all events in the orogen that preceded intrusion of the Ben Vuirich granite took place during the Precambrian.

The conclusions of Rogers et al. were confirmed by a more recent development in the analysis of zircons based on in-situ, ionmicroprobe analysis. Precise though the methods of Krogh undoubtably are, they remain extremely time-consuming. The Sensitive High-Resolution Ion Microprobe (SHRIMP) that was originally constructed in 1977, allows multiple analyses to be obtained rapidly from individual crystals by focussing a beam of ions a few microns across onto an in-situ zireon grain (Compston et al., 1984). When applied to the Ben Vuirich zircons the euhedral arains provided an age of $597 \pm 11 \mathrm{Ma}$ (Pidgeon and Compston, 1992), within error of the age obtained by Rogers et al. (1989). The stubby grains provided cores in two separate age ranges; $\sim 1000 \mathrm{Ma}$ and $\sim 1700 \mathrm{Ma}$. This illustrates the power of the SHRIMP technique where cores of more than one age are present.

For very young granites, no technique is entirely satisfactory as proportional errors on the ages increase with decrease in their absolute values. Nonetheless some extraordinarily young granites have been identified using the ion microprobe. Small crustally derived granites from the Nanga Parbat area of the western Himalayas are emplaced into metasediments that have undergone unusually rapid exhumation over the past $5 \mathrm{Ma}$. U-Pb ages on zircons from the granites, obtained by the SHRIMP technique (Zeitler et al., 1993), indicate a crystallisation age of 1 to 2 Ma with xenocrystic crystals (inherited from their Precambrian protoliths) yielding an age of $\sim 1850 \mathrm{Ma}$. Although the proportional errors on the crystallisation ages are high the results allow thermal models that relate exhumation to decompression melting to be tested. It is unlikely that any other technique could yield such results in so young a tectonic belt.

However the technology required for ion-microprobe analysis is expensive, each machine costing several million dollars. Zircons can be dated using a third development that is less labour intensive than the physical separation and dissolution required by conventional techniques, and less expensive than the ion-microprobe. The thermal evaporation of $\mathrm{Pb}$ from individual zircon grains has been refined by Kober (1986) to yield a sequence of ${ }^{207} \mathrm{~Pb} / 206 \mathrm{~Pb}$ ratios from rim to core during zircon evaporation through a sequence of temperature increments. $\mathrm{Pb}$ from the most retentive sites in the crystal is released at the highest temperatures. Although rapid and relatively cheap, there remain two problems with the general application of this technique. Firstly ${ }^{207} \mathrm{~Pb} /{ }^{206} \mathrm{~Pb}$ ratios only yield true crystallisation ages when the zircon is concordant (i.e. has not suffered $\mathrm{Pb}$ loss). Unlike conventional $\mathrm{U}-\mathrm{Pb}$ analysis of zircons there are no independent means of assessing the degree of discordance of the zircon with the evaporation technique. Secondly it is difficult to evaluate the accuracy of the Kober technique, although the concept of a 'reliability index' has recently been proposed (Dougherty-Page and Foden, 1996). In general the technique is most appropriate for old zircons ( $>100$ million years) that are strictly concordant.

\section{Mineral chronometry using multiple phases}

Zircon is not the only phase that may be used for dating the age of crystallisation in granites. Monazite ( $\mathrm{Ce}$, Th phosphate) is also a common accessory, particularly in peraluminous granites. Like zircon it has negligible initial $\mathrm{Pb}$, and a high $\mathrm{U}$ content so that ages can be obtained by conventional means by analysis of only a few grains. There are some problems peculiar to monazite analysis that result from excess ${ }^{206} \mathrm{~Pb}$ from ${ }^{230} \mathrm{Th}$ decaly, but these can be compensated if the $\mathrm{Th} / \mathrm{U}$ ratio in the magma can be properly assessed. Monazites have been found to yield concordant ages in many granite studies although. like zircon, they can also incorporate inherited components. In one study of the Everest leucogranite both zircon and monaxite incorporated inherited cores (Copeland et al., 1988), and the true emplacement age $(20.6 \mathrm{Ma})$ was obtained from the Y-phosphate, xenotime (Parrish, 1990).

Recently, a monazite dating technique has been proposed that dispenses with the need for a mass spectrometer. Using a standard electron microprobe to analyse elemental concentrations of $\mathrm{U}, \mathrm{Th}$ and $\mathrm{Pb}$ concentrations in monazites within a polished thin section, an age can be calculated if several rather critical assumptions are made (Montel et al.. 1996). The disadvantages of this obviously convenient and cheap method of age determination are that the ${ }^{204} \mathrm{~Pb}$ contents are unknown and the concordance of the monazite must be

Table 1 Common phases used for mineral chronometry in granite studies.

\begin{tabular}{lllll} 
& Formula & Closure T $\left({ }^{\circ} \mathrm{C}\right)$ & Decay System & Occurrence \\
\hline Zircon & $\mathrm{ZrSiO}_{4}$ & $>800$ & $\mathrm{U}-\mathrm{Pb}$ & $\mathrm{MG}, \mathrm{PG}, \mathrm{AG}$ \\
Monazite & $\mathrm{CePO}_{4}$ & $720-750$ & $\mathrm{U}-\mathrm{Pb}, \mathrm{Th}-\mathrm{Pb}$ & $\mathrm{PG}, \mathrm{AG}$ \\
Xenotime & $\mathrm{YPO}_{4}$ & $\sim 750 ?$ & $\mathrm{U}-\mathrm{Pb}$ & $\mathrm{PG}, \mathrm{AG}$ \\
Allanite & $\mathrm{CaFeAl}_{2} \mathrm{Si}_{3} \mathrm{O}_{12}$ & $750-800$ & $\mathrm{U}-\mathrm{Pb}, \mathrm{Th}-\mathrm{Pb}$ & $\mathrm{MG}$ \\
Sphene & $\mathrm{CaTiO}_{3}$ & $500-670$ & $\mathrm{U}-\mathrm{Pb}$ & $\mathrm{MG}$ \\
Hornblende & $\mathrm{Ca}_{2}\left(\mathrm{Mg}_{2}, \mathrm{Fe}\right)_{4} \mathrm{Al} \mathrm{Si}_{7} \mathrm{O}_{22}(\mathrm{OH})_{2}$ & $450-550$ & $\mathrm{Ar}-\mathrm{Ar}$ & $\mathrm{MG}$ \\
Muscovite & $\mathrm{KAl}_{3} \mathrm{Si}_{3} \mathrm{O}_{10}(\mathrm{OH})_{2}$ & $500-550$ & $\mathrm{Rb}-\mathrm{Sr}$ & $\mathrm{PG}$ \\
& & $300-400$ & $\mathrm{Ar}-\mathrm{Ar}$ & \\
Biotite & $\mathrm{K}(\mathrm{Mg}, \mathrm{Fe})_{3} \mathrm{Si}_{3} \mathrm{AlO}_{10}(\mathrm{OH})_{2}$ & $250-350$ & $\mathrm{Rb}-\mathrm{Sr}$ & MG, PG, AG \\
& & $250-350$ & $\mathrm{Ar}-\mathrm{Ar}$ & \\
\hline
\end{tabular}


assumed, so consistency between a large number of analyses is essential. Age uncertainties are $\pm 20 \mathrm{Ma}$ at best, and the technique is only useful for rocks older than a few hundred million years.

Each phase used for mineral chronometry has a fairly narrow temperature range through which the structure becomes closed to loss of the daughter isotope which is known as its closure temperature (Table 1). If a crystallisation age is being sought through mineral chronometry then the closure temperature for the mineral concerned must exceed the solidus temperature of the crystallising granite. If the closure temperature is lower than the solidus temperature then a cooling age will be obtained. By careful selection of mineral chronometers both the time of crystallisation and the subsequent cooling history can be unravelled.

A recent study of the Bergell multiple intrusion in the Italian Alps (Von Blanckenburg, 1992) illustrates the detailed information that can be derived from integrating the results from isotopic analysis of several accessory phases. Zircon fractions (from which crystals with obvious cores were excluded) yielded a concordant $\mathrm{U}-\mathrm{Pb}$ age of $31.88 \pm 0.09 \mathrm{Ma}$ for the tonalitic facies of the intrusion. However zircons from the granodiorite facies yielded much less precise ages in the range $26-31 \mathrm{Ma}$, due to $\mathrm{Pb}$ loss, associated with radiation damage. Allanite is a Ce-Th-rich epidote that can yield both ${ }^{206} \mathrm{~Pb} /{ }^{238} \mathrm{U}$ and ${ }^{208} \mathrm{~Pb} /{ }^{232} \mathrm{Th}$ ages; for the tonalite the $\mathrm{U}-\mathrm{Pb}$ age was $\sim 34.1 \mathrm{Ma}$ and the $\mathrm{Th}-\mathrm{Pb}$ age $31.5 \pm 0.3 \mathrm{Ma}$. These results are significant; firstly they show that U-Pb ages from accessory phases can be erroneously high, due to an incorrect estimation of $\mathrm{U} / \mathrm{Th}$ in the melt which can be fractionated by the crystallisation of Th and U-rich accessory phases. Secondly $\mathrm{Th}-\mathrm{Pb}$ ages from allanite can yield crystallisation ages, suggesting a high closure temperature for $\mathrm{Pb}$ isotopes $\left(>750^{\circ} \mathrm{C}\right)$. Allanite from the granodiorite yielded $\mathrm{U}-\mathrm{Pb}$ and $\mathrm{Th}-\mathrm{Pb}$ ages of 30.5 and $30.16 \mathrm{Ma}$ respectively and their concordance suggests they define a crystallisation age of greater precision than is possible using zircon. Other accessory phases in the tonalite, sphene (titanite) and apatite, yielded ages of $\sim 29 \mathrm{Ma}$, similar to cooling ages obtained from ${ }^{40} \mathrm{Ar}-{ }^{39} \mathrm{Ar}$ dating of hornblende. Such ages are important since they allow cooling rates to be estimated, and for orogenic granites these rates can test the validity of competing tectonic models, but it is obviously vital to be able to distinguish crystallisation ages from cooling ages (Table 1). One further conclusion drawn from this elegant study is that allanite is an extremely useful mineral for dating calc-alkaline granitic rocks; it appears to be rarely inherited and $\mathrm{Th}-\mathrm{Pb}$ and $\mathrm{U}-\mathrm{Pb}$ ages can be compared to test for $\mathrm{Pb}$ loss (this is also true for conventional monazite chronometry).

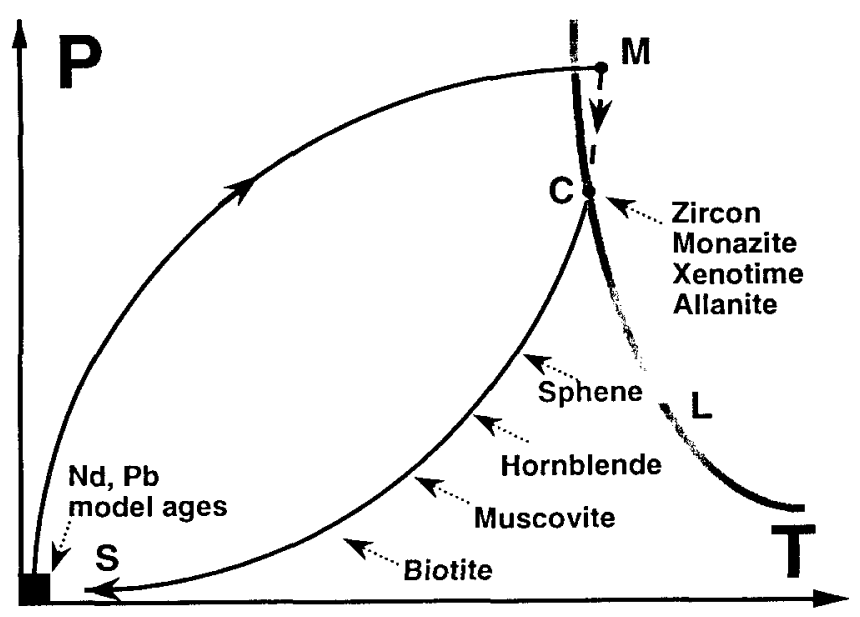

Figure 3 Hypothetical P-T loop for granite and its protolith. Burial of the protolith causes melting at $M$ above the solidus (curve $L)$; melt rises and crystallises at $C$; crystallised granite is tectonically exhumed and exposed at the surface at $S$. Also indicated schematically are appropriate mineral chronometers along $P-T$ loop and relevant techniques for dating protolith (filled square).
The relationship between the various techniques discussed in this review is illustrated in Figure 3. Here a hypothetical pressure-temperature path of the sedimentary protolith of a granite is shown during burial. Melt formation occurs as it crosses the granite solidus (here assumed to be water-saturated). Rapid ascent of the melt to cooler crustal levels leads to crystallisation at $C$; this event can be dated using specific accessory phases with closure temperatures above the solidus temperatures. These include zircon, monazite, xenotime or allanite for low-temperature granites although for higher-temperature melts only zircon may yield a true crystallisation age. Crystallisation is followed by unroofing and cooling until exposed at the surface (S). This cooling path may be dated by sphene, hornblende, muscovite and biotite chronometers with successively decreasing closure temperatures.

\section{Source regions of granites}

Radiogenic isotopes can be used not only to date the age of crystallisation of a melt, but also to indicate the relative contributions of crustal and mantle sources to its formation and, in the case of crustal melts, the age of its source region. As already discussed, accessory phases like zircon and monazite can be inherited during partial melting of the source. Often an age for the source region is a by-product from the determination of the crystallisation age as was the case in the study of the Ben Vuirich and Everest intrusions. Isotopic ratios can also be used as geochemical fingerprints of the source region. The most common example in the literature is the ${ }^{87} \mathrm{Sr} /{ }^{86} \mathrm{Sr}$ ratio of the granite calculated at the time of intrusion (its initial Sr-isotope ratio). This ratio provides an effective way of identifying a crustal component in the origin of a granite since much of the continental crust (with a high $\mathrm{Rb} / \mathrm{Sr}$ ratio) is characterised by higher ${ }^{87} \mathrm{Sr} /{ }^{86} \mathrm{Sr}$ ratios than the upper mantle. This approach depends on a precise knowledge of the crystallisation age of the granite. Returning to Ben Vuirich, the Rb-Sr data of Pankhust and Pidgeon (1976) when recalculated to the zircon age of Rogers et al. (1989) yields a range of initial ${ }^{87} \mathrm{Sr} /{ }^{86} \mathrm{Sr}$ ratios between 0.7146 and 0.7150 ; this highlights the lack of homogenisation in the melt and also the high ratio which implies a crustal component in the origin of the granite.

The age of granite source regions can also be constrained using model ages. Such an approach has been used for both $\mathrm{Pb}$ and $\mathrm{Nd}$ isotopes, and rests on the fact that critical elemental ratios $(\mathrm{U} / \mathrm{Pb}, \mathrm{U} / \mathrm{Th}$ or $\mathrm{Sm} / \mathrm{Nd}$ ) are fractionated during partial melting of the mantle. If the subsequent behaviour of these ratios within the crust can be properly understood then model ages can yield the time elapsed since the source region of the granite became part of the crust. This means that provided granites have remained as closed systems, their isotopic ratios can potentially be used to fingerprint their source regions, discriminate between tectonic terranes and constrain crustal growth models (Harris et al., 1990).

$\mathrm{Pb}$ and $\mathrm{Nd}$ isotopes provide different geochemical information. $\mathrm{Pb}$ is enriched in the crust by a factor of 100 relative to mantle, four times the value for $\mathrm{Nd}$, so Pb derived from an oceanic source is more readily contaminated during ascent. Moreover $\mathrm{U} / \mathrm{Pb}$ ratios show much more variation in crustal rocks than do $\mathrm{Sm} / \mathrm{Nd}$, so that whereas $\mathrm{Pb}$ isotopes are a more powerful tool in distinguishing between different crustal processes, crustal growth periods are better identified through Nd studies.

In general, a model $\mathrm{Nd}$ age reflects the time elapsed since the sample was extracted from a given reservoir, usually taken as the depleted mantle (TDM). The isotopic ratio ${ }^{143} \mathrm{Nd} /{ }^{144} \mathrm{Nd}$ in a sample increases through time at a rate proportional to its $\mathrm{Sm} / \mathrm{Nd}$ ratio. Since it has been argued that the elemental ratio is unaffected by crustal processes $\mathrm{Nd}$ isotope studies of granites have been used to estimate the time at which crustal growth occurred (DePaolo, 1981). Only if the granite is a simple product of fractional crystallisation of a melt formed from partial melting of the upper mantle will its model $\mathrm{Nd}$ age equal its emplacement age. In the case of a crustal melt the model $\mathrm{Nd}$ age will provide the time at which the source region of the granite was derived from the mantle. If derived from several sources 
than the model $\mathrm{Nd}$ age will be a weighted average age of contributing sources.

From this it can be seen that for many granites, resulting from complex interactions between magmas derived at subduction zones and crustal assimilation, the model $\mathrm{Nd}$ age will have no strict geological meaning. For simple crustal melts derived from a single lithology, or from several lithologies of the same age, the model $\mathrm{Nd}$ age will, in principle, yield the age of the protolith. However several studies of anatectic granites (Inger and Harris, 1993, and references therein) indicate that unusually high $\mathrm{Sm} / \mathrm{Nd}$ ratios characterise many high $\mathrm{SiO}_{2}$ granites ( $>72 \%$ ) which results in anomalous model $\mathrm{Nd}$ ages. This is unsurprising since the interpretation that a model $\mathrm{Nd}$ age indicates the crustal residency of the sample rests on the assumption that the $\mathrm{Sm} / \mathrm{Nd}$ ratio remains unfractionated during its crustal history.

A recent study of the distribution of $\mathrm{REE}$ in Himalayan metapelitic rocks indicates that $>99 \%$ of $\mathrm{Nd}$ and $\mathrm{Sm}$ reside in two accessory phases; monazite and apatite (Ayres and Harris, 1997). The abundances of these elements in the melt depends on their saturation levels that are buffered by the dissolution of monazite. The saturation levels in turn depends on the temperature and water content of the melt. In general the $\mathrm{Sm} / \mathrm{Nd}$ ratio of low temperature melts will be particularly high. leading to anomalously large model $\mathrm{Nd}$ ages. This is illustrated in Figure $4 \mathrm{a}$ where sedimentary source rocks for Himalayan granites, like most crustal rocks, are characterised by a narrow range of $\mathrm{Sm} / \mathrm{Nd}$ ratios, whereas a marked increase in $\mathrm{Sm} / \mathrm{Nd}$ ratios is observed in many Himalayan granites. From the metasedimentary lithologies, model ages of 1900-2100 Ma are obtained. The effect of $\mathrm{Sm} / \mathrm{Nd}$ fractionation in the melt is clearly shown in Figure 4 b where calculated ages rise to $>4.5 \mathrm{Ga}$, the age of the Earth!

Because Sm/Nd fractionation renders model Nd ages of highsilica melts virtually meaningless, such calculations are better applied to the source rocks from which the granites are derived than to the granites themselves. Where the source rocks are unknown it is better to assume an average crustal $\mathrm{Sm} / \mathrm{Nd}$ ratio than to assume that the $\mathrm{Sm} / \mathrm{Nd}$ ratio of the granite is unfractionated. The same is true of model $\mathrm{Pb}$ ages since the initial $\mathrm{Pb}$-isotope composition of a granite is derived in part from major phases such as feldspars, micas and amphiboles, with low ${ }^{238} \mathrm{U} /{ }^{204} \mathrm{~Pb}$ and ${ }^{2.32} \mathrm{Th} /{ }^{204} \mathrm{~Pb}$ ratios and partly from accessory phases such as zircon and monazite with highly radiogenic ratios. In general peraluminous granites that are generated at low temperatures $\left(<750^{\circ} \mathrm{C}\right)$ have homogencous $\mathrm{Pb}$ isotope signatures dominated by major plases. Since dissolution of accessory phases is highly sensitive to temperature, higher temperature peralkaline or metalumionus granites are characterised by heterogeneous $\mathrm{Pb}$ isotopes with a higher proportion of $\mathrm{Pb}$ being derived from monazite and zircon (Hogan and Sinha, 1991).

\section{Isotopic disequilibrium and the measurement of geological rates}

The identification of the source regions of igneous rocks from analysis of appropriate isotopic ratios is an approach underpinned by the assumption that melts inherit the same isotopic ratio as their bulk sources at the time of their formation. But it may be that for some granites this is not the case. Equilibrium between melt and restite occurs through diffusion which is controlled by temperature; granites being the lowest temperature silicate melts that can form are therefore susceptible to disequilibrium. Disequilibrium is a very important phenomenon since if appropriate diffusion coefficients are known quantitative constraints can be placed on the rates of prograde heating in the protolith, and of melt extraction. Such information is particularly valuable since even where peak thermal conditions and the retrograde path of mineral assemblages are well defined by phase equilibria and chronometric studies, the prograde history of the thermal event remains poorly understood.

$\mathrm{Sr}$-isotope disequilibrium between melt and source during crustal melting has been observed in nature and reproduced in labo-

\section{(a)}

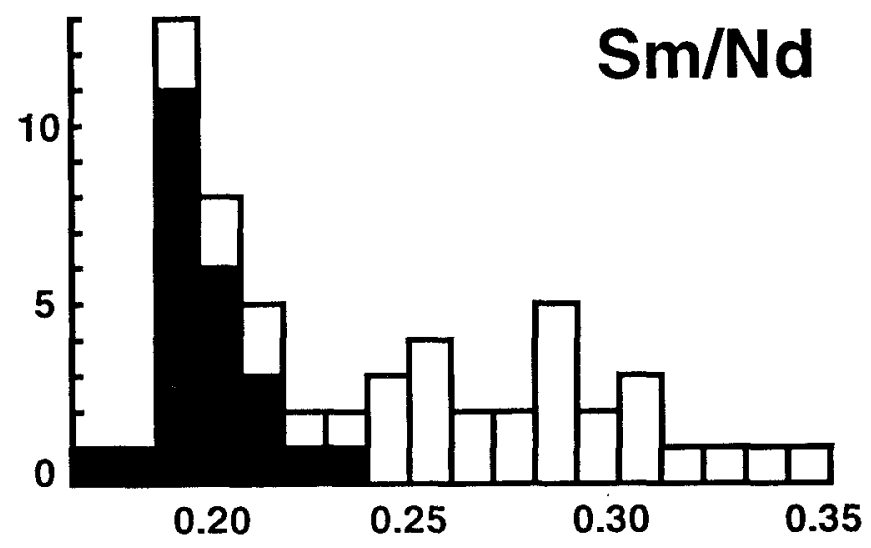

\section{(b)}

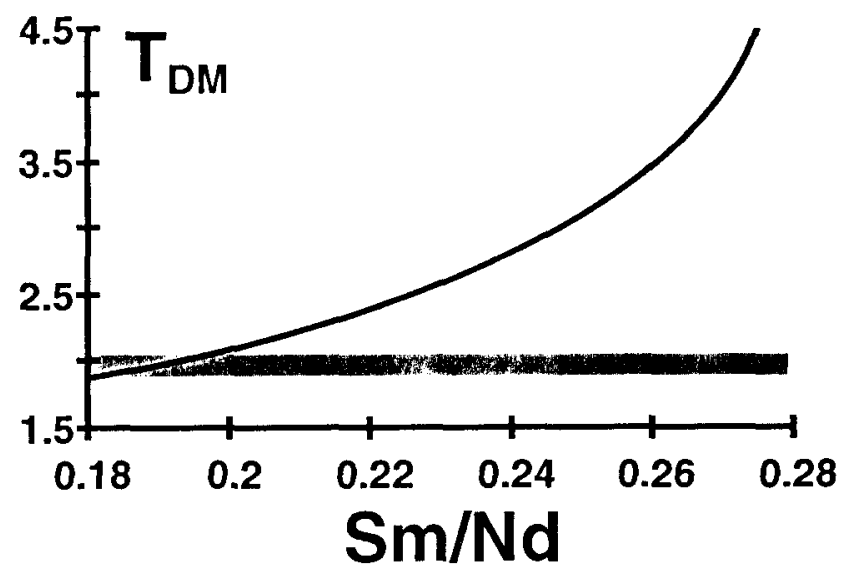

Figure 4 (a) Histogram of $\mathrm{Sm} / \mathrm{Nd}$ ratios from High Himalayan granites (open bars) and from their metasedimentary protoliths (filled bars); vertical axis $=$ number of samples. Data from Ayres and Harris (1997) and references therein. (b) Effect of fractionating $\mathrm{Sm} / \mathrm{Nd}$ ratio in melt on calculated model $N d$ age (TDM) for Himalayan granites. Horizontal shaded field indicates range of model Nd ages obtained from metasedimentary protoliths.

ratory experiments. Anatectic granites derived from their protoliths by biotite breakdown during the Hercynian event have been found to retain lower initial ${ }^{87} \mathrm{Sr} /{ }^{86} \mathrm{Sr}$ ratios (by about 0.005 ) than their pelitic protoliths (Barbero and Villaseca, 1995). Experimental studies confirm that partial melting of a plagioclase-mica protolith can result in elevated ${ }^{87} \mathrm{Sr} /{ }^{86} \mathrm{Sr}$ ratios in the melt due to the faster melting kinetics of mica (Knesel and Davidson, 1996).

A compilation of initial $\mathrm{Sr}$-isotope ratios for the Manaslu Himalayan leucogranite and its inferred metasedimentary protolith is given in Figure $5 \mathrm{a}$. A casual glance reveals that the isotopic ratios from the metasediments cover a larger range than those from the derived melts, possibly because anatexis results from the melting of several horizons thus generating a weighted mean composition from the contributing sources. More detailed analysis of individual granites and their sources suggests that disequilibrium of ${ }^{87} \mathrm{Sr} /{ }^{86} \mathrm{Sr}$ can be no larger than 0.002 between melt and source. Using published tracer diffusion rates for plagioclase this observation translates into a minimum equilibration period of $\sim 200 \mathrm{ka}$ (Harris and Ayres, 1996). Since isotopic equilibration is initiated in the protolith when it is 
(a)

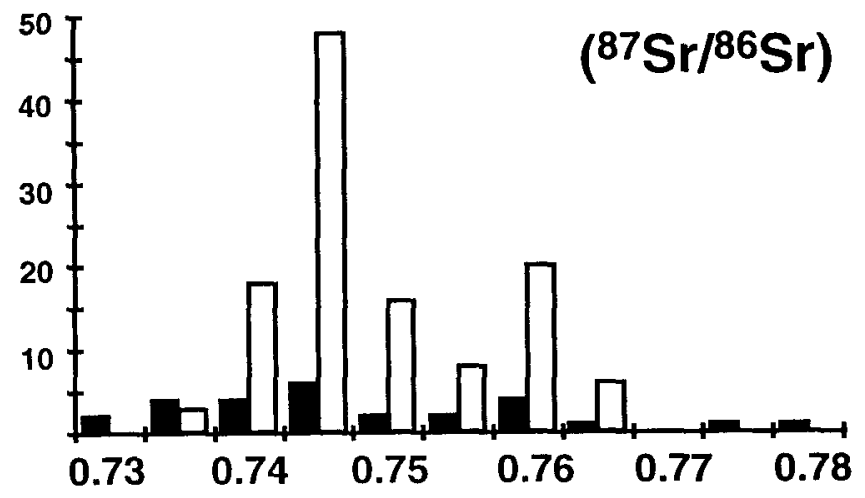

(b)

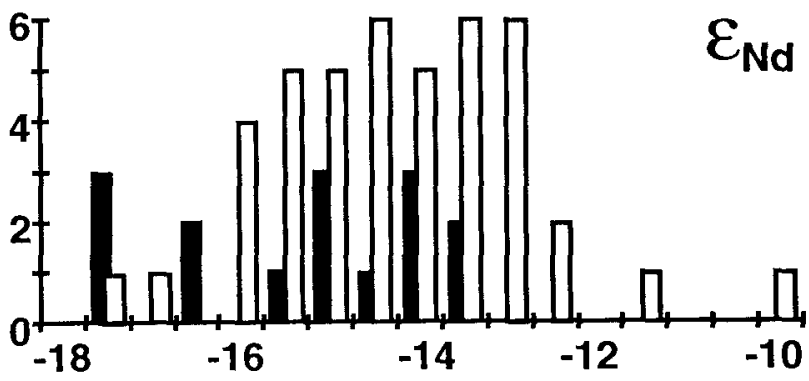

Figure 5 (a) Histogram of ${ }^{87} \mathrm{Sr} /{ }^{86} \mathrm{Sr}$ isotope ratios (calculated at $20 \mathrm{Ma}$ ) from Manaslu intrusion (Nepalese Himalayas). Data from Guillot and Le Fort (1995) and sources therein. (b) Histogram of ${ }^{143} \mathrm{Nd}^{144} \mathrm{Nd}$ ratios (calculated as $\varepsilon_{N d}$ at $20 \mathrm{Ma}$ ) from High Himalayan intrusions. Data from Ayres and Harris (1997) and references therein. For both plots, vertical axis $=$ number of analyses, filled bars = metasedimentary samples, open bars = granite samples.

heated above about $600^{\circ} \mathrm{C}$, it suggests that in the Himalayan example the period that elapsed between prograde heating above $600^{\circ} \mathrm{C}$ and melt extraction from source must have exceeded $200 \mathrm{ka}$. The equilibration period for $\mathrm{Sr}$ is probably taken up largely by prograde heating of the protolith since melt extraction rates are likely to be rapid for orgenic granites. Recent experimental studies suggest granite melts can be extracted over a period of $1-50 \mathrm{ka}$ through a combination of shear-enhanced compaction and vein network flow (Rutter and Neumann, 1995). Direct evidence for granite melts being extracted over such short timescales has been obtained by relating the trace-element geochemistry of crustally derived granites to the relative dissolution rates of accessory phases in granite magmas (Ayres et al., 1996)

Although the time constraint of 200 ka obtained from Sr equilibration kinetics rules out unusually rapid heating models, such as frictional heating on thrusts or advective heating by basic magmas, it is likely that in most orogenic belts heating rates will be slow so that disequilibrium of $\mathrm{Sr}$ isotopes in granites will only rarely be observed. It would therefore be more useful to have an isotopic system characterised by slower diffusion rates. Figure $5 b$ compares the $\mathrm{Nd}$-isotope ratio of Himalayan granites with their metasedimentary protoliths (in e notation). In this case there is a definite shift in melts towards higher ${ }^{143} \mathrm{Nd} /{ }^{144} \mathrm{Nd}$ ratios relative to their sources. Since the $\mathrm{Nd}$ distribution in Himalayan metasedimentary rocks is concentrated in two accessory phases (monazite and apatite) the degree of disequilibrium plotted in Figure $5 \mathrm{~b}$ relates to diffusion rates of $\mathrm{Nd}$ in these phases. Unfortunately at present the diffusion coefficients of neither phase is well-constrained by experiment, but it remains a major goal of isotope geochemistry to obtain constraints on the rates of heating and of melt extraction by application of appropriate diffusion data to observed isotopic disequilibrium in natural systems.

\section{Acknowledgments}

The author thanks Chris Hawkesworth, Derek Vance, Simon Turner and Mike Ayres for constructive discussion during the preparation of this article.

\section{References}

Ayres, M, Vance, D, and Harris, N, 1996, Possible constraints on anatectic melt residence times from accessory mineral dissolution rates: an example from Himalayan leucogranites: Mineralogical Magazine, v. 40 (in press)

Ayres, M, and Harris, N, 1997, REE and Nd-isotope fractionation during crustal anatexis: constraints from Himalayan leucogranites: Chemical Geology (in press).

Barbero, L, and Villaseca, C, 1995, Geochemical and isotopic disequilibrium in crustal melting: an insight from the anatectic granitoids from Toledo, Spain: Journal of Geophysical Research. v. 100, pp.15745-1576.5.

Compston, W, Williams, I S, and Meyer, C, 1984, U-Pb geochronology of zircons from lunar breccia 73217 using a high mass-resolution ion microprobe: Journal of Geophysical Research, v. 89B, pp.525-534.

Copeland. P, Parrish, R R, and Harrison, T M. 1988, Identification of inherited radiogenic $\mathrm{Pb}$ in monazite and its implications for $\mathrm{U}-\mathrm{Pb}$ systematics: Nature, v. 333, pp.760-763.

Copeland, P, Harrison, T M, and Le Fort, P, 1990, Age and cooling history of the Manalsu granite: implications for Himalayan tectonics: Journal of Volcanology and Geothermal Research, v. 44, pp.33-50.

Deniel, C, Vidal, P, Fernandez, A, Le Fort, P, and Peucat, J J, 1987, Isotopic study of the Manaslu granite (Himalaya, Nepal): inferences of the age and source of Himalayan leucogranites: Contributions to Mineralogy and Petrology, v. 96, pp. $78-92$.

De Paolo, D J, 1981. Nd isotopes in the Colorado Front Range and crust-mantle evolution in the Proterozoic: Nature, v. 291, pp.193 196.

Dougherty-Page, J S, and Foden, J, 1996, A Pb-Pb zircon evaporation date for the Charleston Granite: Comparisons with other zircon geochronology techniques: Australian Journal of Earth Sciences, (in press).

Guillot, S, Hodges, K., Le Fort, P, and Pecher, A, 1994, New constraints on the age of the Manaslu leucogranite: Evidence for cpisodic tectonic denudation in the central Himalayas: Geology, v. 22, pp.559-562.

Guillot, S, and Le Fort. P, 1995, Geochemical constraints on the bimodal origin of High Himalayan leucogranites: Lithos, v. 35, pp.221-234.

Harris, N B W, Gass. I G, and Hawkesworth, C J, 1990, A geochemical approach to allochthonous terranes: a Pan-African case-study: Philosphical Transactions of the Royal Socicty. London, v. A331, pp.533-548.

Harris, N, and Ayres, M. 1996, The implications of Sr-isotope disequilibrium for rates of prograde metamorphism and melt extraction in anatectic terrains (abs): 'What drives metamorphic reactions?' Abstracts with Programme, University of Kingston, pp.35-36.

Harrison, T M, and McKeegan, K D, 1994, ${ }^{208} \mathrm{~Pb} /{ }^{23}{ }^{2} \mathrm{Th}$ ion microprobe dating of monazite and Himalayan tectonics (abs): Geological Society of America Abstracts with Programs, v. 26, pp.A-367.

Hogan, J P, and Sinha, A K, 1991, The effect of accessory minerals on the redistribution of lead isotopes during crustal anatexis: A model: Geochimica et Cosmochimica Acta, v. 55, pp.335-348.

Inger, S and Harris, N B W, 1993, Geochemical constraints on leucogranite magmatism in the Langtang Valley, Nepal Himalaya: Joumal of Petrology, v. 34 , pp. $345-368$.

Knesel, K M, and Davidson, J P, 1996, Isotopic disequilibrium during melting of granite and implications for crustal contamination of magmas: Geology, v. 24, pp. 243-246

Kober, B, 1986, Whole-grain evaporation for ${ }^{207} \mathrm{~Pb} /{ }^{206} \mathrm{~Pb}$ age investigations on single filiaments using a double-filiament thermal ion source: Contributions to Mineralogy and Petrology, v. 93, pp.482-490.

Krogh, T E, 1982. Improved accuracy of $\mathrm{U}-\mathrm{Pb}$ zircon dating by the creation of more concordant systems using an air abrasion technique: Geochimica et Cosmochimica Acta, v. 46, pp.637-649. 
Le Fort, P. 1991, Enclaves of the Miocene Himalayan leucogranites, in Didier, J, and Barbarin, B, eds., Enclaves and granite petrology: Elsevier, Amsterdam, pp.35-46.

Montel, J-M, Foret, S, Veschambre, M. Nicollet, C, and Provost, A, 1996, A fast, non-expensive, reliable, in situ dating technique: Electron microprobe ages on monazite: Chemical Geology (in press).

Pankhurst, R J, and Pidgeon, R T, 1976, Inherited isotope systems and source region pre-history of early Caledonian granites in the Dalradian series of Scotland: Earth and Planetary Science Letters, v. 31, pp.55-68.

Parrish, R R, 1990, U-Pb dating of monazite and its application to geological problems: Canadian Journal of Earth Sciences, v. 27, pp.1431-1450.

Pidgeon, R T, and Compston, W, 1992, A SHRIMP ion microprobe study of inherited and magmatic zircons from four Scottish Caledonian granites. in Brown, P E, and Chappell, B W, eds, Second Hutton Symposium on the Origin of Granites and Related Rocks: Transactions of the Royal Society of Edinburgh, v. 83, pp.473-483.

Rogers, G, Dempster, T J, Bluck, B J, and Tanner, P W G, 1989, A high-precision U-Pb age for the Ben Vuirich granite: implications for the evolution of the Scottish Dalradian Supergroup: Journal of the Geological Society, London, v. 146, pp.789-798.

Rutter, E H, and Neumann, D H K, 1995, Experimental deformation of partially molten Westerly granite under fluid-absent conditions with implications for the extraction of granitic magmas: Journal of Geophysical Research, v. 100, pp.15697-15715.
Von Blanckenburg, F, 1992, Combined high-precision chronometry and geochemical tracing using accessory minerals: applied to the Central-Alpine Bergell intrusion (central Europe): Chemical Geology, v. 100, pp.19-40.

Zeitler, P K, Page Chamberlain, C, and Smith, H A, 1993, Synchronous anatexis, metamorphism, and rapid denudation at Nanga Parbat: Geology, v. 21, pp.347-350.

Nigel Harris is Director of Research and Senior Lecturer in the Department of Earth Sciences, Open University (UK). Initially a metamorphic petrologist at Cambridge University, he now seeks to link igneous geochemistry with physical processes involved in magma formation. He has studied diverse granitoid provinces around the world and since 1985 his main interest has been in the evolution of collision zones, particularly through the study of granites in Tibet and the Himalayas.

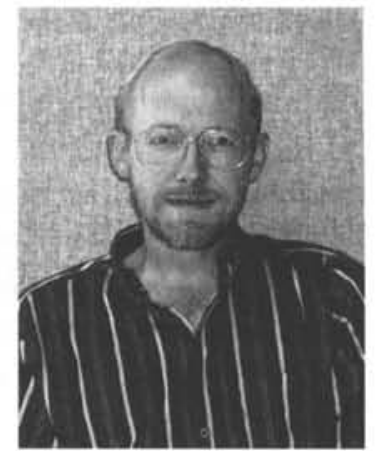

